\title{
Pastoral care as a resource for development in the global healthcare context: Implications for Africa's healthcare delivery system
}

Authors:
Emem Agbiji
Obaji Mbeh Agbiji2
Affiliations:
'Department of Philosophy,
Practical and Systematic
Theology, University of South
Africa, South Africa
2Research Institute for
Theology and Religion,
University of South Africa,
South Africa
Corresponding author:
Emem Agbiji,
treasureofpeace@yahoo.com
Dates:
Received: 28 May 2016
Accepted: 29 Aug. 2016
Published: 06 Dec. 2016
mobile device
to read online.
How to cite this article:
Agbiji, E. \& Agbiji, O.M.,
2016, 'Pastoral care as a
resource for development in
the global healthcare
context: Implications for
Africa's healthcare delivery
system', HTS Teologiese
Studies/Theological Studies
72(4), a3507. http://dx.doi.
org/10.4102/hts.v72i4.3507
Copyright:
co 2016. The Authors.
Licensee: AOSIS. This work
is licensed under the
Creative Commons
Attribution License.

Development is concerned with the transformation of people to foster their health, wholeness and growth. The link between health and development points to religion as potential social capital for development. There is an ongoing debate about the role of pastoral care as a religious resource in global healthcare contexts. This is unfortunately not the case in Africa, as pastoral care has not received sufficient attention for its role in healthcare and development in development discourses. The limited research on pastoral care in healthcare contexts in Africa has implications for African healthcare systems, pastoral care and the delivery of an effective, holistic and quality healthcare service. Taking as its point of departure a thesis about the potential of religion as a social capital resource for development, the article argues for pastoral care as a viable religious resource for healthcare and development. Osmer's theological task of good practice is employed as an interdisciplinary engagement in dialogue with selective perspectives in the disciplines of development and health and social sciences for appropriate analysis.

\section{Introduction}

Scholars in the field of development such as Davids (2008:23), Agbiji (2012:284, 291), Belshaw, Calderisi and Sudgen (2001:3), and Cochrane (2011:233) believe that development is about the well-being of persons within the interconnecting networks of human relations in the international, national and community contexts. Such relations are often presumed to foster health, wholeness and growth. Consequently, the health of the people is considered a key determinant for measuring poverty and the level of development of people and communities, which means the more healthy the citizens of a country, the more developed the country is, and vice versa (Sachs 2005:194; Schmid, Cochrane \& Olivier 2010:139-149). Statistics show that the so-called developed world has a higher life expectancy rating than the so-called developing countries. According to the 2014 World Health Statistics Report, the average life expectancy of people in African countries is in the range of 50-60 years; in the developed countries, it is in the range of 70-80 years (WHO 2014:68).

Health as an indicator of the development level of people suggests that people need holistic care and support in their environment, as conditions of sickness and suffering may impact their sense of meaning and purpose in their daily interactions - which is of psychological and spiritual significance. This psychological and spiritual significance relate to the search for meaning and purpose in life. Contrary to the marginalisation of religion in development research in the past, there is now considerable research evidence that religion, as social capital, can help to alleviate poverty and suffering in various forms (Cochrane 2011:231-252; Schmid et al. 2010:139-149; Ter Haar \& Ellis 2006:351-367; Wepener et al. 2010:61-82). Scholars from the field of development note the growing interest of governments, researchers, academics and funding agencies in religion and religious organisations. The link between health and religion for human development thus raises certain concerns that demand attention. How can religion be used for the development and transformation of people, particularly in the healthcare context? Who should be responsible for such an endeavour? Can pastoral care as a religious discipline and practice be effectively used as one of the development models in healthcare in the African context? Is there any link between pastoral care (as God's activity in society, mediated through competent caregivers) and development?

There is an ongoing debate about pastoral care as a professional discipline and practice in healthcare contexts in places such as Europe, the USA and Australia. Yet pastoral care as a

Note: This article was supported by the National Research Foundation (NRF) of South Africa under grant nos. 88489 and 85113 respectively. Any opinions, findings, conclusions or recommendations expressed in this article are those of the authors and therefore the NRF do not accept any liability in regard thereto.

This article forms part of the special collection on 'Engaging development: Contributions to a critical theological and religious debate' in HTS Teologiese Studies/Theological Studies Volume 72, Issue 4, 2016 
professional discipline and practice has not received sufficient attention in development discourse, or for its role in healthcare institutions in Africa. Perhaps this scant attention could be related to the narrow conception of pastoral care, which narrows it practices with the ecclesial context. Little research has been done on the role of pastoral care in healthcare institutions in Africa. The few works that are relevant to this discussion include those of Agbiji (2013), De la Porte (2013) and Neethling (2003). The limited research on the interface between pastoral care and healthcare may have several implications for pastoral care in African healthcare delivery systems. The insufficient attention given to pastoral care questions the value that African scholarship, governments and practitioners place on pastoral care as a religious resource for the sick and vulnerable who seek relief and empowerment in healthcare institutions.

Taking as our point of departure the thesis about the potential of religion as a social capital resource for development, we argue that pastoral care - as a discipline as well as practice offers religious resources that can effectively be utilised in caring for patients and promoting their well-being. This is because pastoral care is essentially concerned with the transformation and wholeness of persons (Agbiji 2013:191). To this end the global context of pastoral caregiving in the hospital context is explored and the implications for pastoral caregiving in the African hospital context are outlined in terms of peoplecentred development. This includes the understanding of pastoral care from a broad perspective that includes but is not limited to pastoral counselling. This endeavour is undertaken through the interdisciplinary hermeneutical lens of practical theology, according to Osmer's (2008:147-152) normative task of good practice. Utilising good practice for normative reflection helps healthcare systems in Africa to generate new insights with which to (re)organise pastoral care by learning from the gains and/or mistakes of other traditions. In addition, it provides resources and guidelines for practice (Osmer 2008:153). Hence, although Osmer's practical theology methodology is asking four questions, this article will utilise two of his tasks, namely the interpretive and normative tasks. These theological tasks are explored in dialogue with selected perspectives in the disciplines of development, sociology and medical science for appropriate analysis.

This article is divided into five sections. In the first section, the background to this article is set out with an analysis of the socio-economic situation in Africa as it relates to health. The second section deals with religion as social capital. The third section presents pastoral care as a religious discipline that can be used for the spiritual development of patients. Guided by the framework of best practice, the practice of pastoral care in healthcare institutions in selected contexts is explored in the global context in the fourth section. The choice of these contexts is guided by the professional, sustained and enduring practice of pastoral care in healthcare settings. In the fifth section, the implications of the current state of pastoral care in healthcare institutions in Africa are identified. In the concluding section, the findings of the study are summarised.

\section{Socio-economic development and health conditions in Africa}

Africa Health Strategy (2007-2015 [2007]) declares that the level of health conditions and the quality of healthcare in Africa is unsatisfactory. According to this overarching document of the Ministers of Health of the member states of the African Union, Africa is still far from attaining its Millennium Development Goals. The present state of health conditions in Africa is ironic when one remembers that health is the most important concern of Africans. It is no wonder that, as a developing continent, Africa experiences slow progress in socio-economic development and health conditions. This slow progress is characterised by the growing disease burden, as seen with diseases such as tuberculosis, HIV and AIDS, and malaria as well as other communicable and non-communicable diseases, trauma and injury. The disease burden is further complicated by inadequate infrastructure, a shortage of personnel, the scarcity of financial resources and the paucity of information and knowledge on best practice; these problems further jeopardise formal health systems in Africa (Africa Health Strategy 2007:2-4; Cochrane 2010:179).

To this end, Jeffery Sachs (2005:188-206), a renowned US economist, dismisses the dominant theories of corruption and poor leadership as responsible for underdevelopment in Africa; he establishes disease as the major factor for Africa's slow development. His conviction is borne out of 10 years of living and conducting research in most parts of Africa. Sachs' research leads him to establish the link between disease or sickness and poverty and to substantiate the hunger-disease nexus.

Without dismissing Sachs' position, Kalu (2010a:296-307) extends the argument regarding poverty and disease by linking the rampant poverty in Africa to the prevalence of violence on the continent. By using the concept of 'social suffering', he argues that 'violence is intricately woven to poverty'. According to Kalu (2010a), a distressed political and social economy inflicts severe stress and health problems on the poor. Violence becomes a channel for releasing anger and tension, and unfortunately 'the poor take it out on themselves' rather than fighting the structures that keep them poor (Kalu 2010a:307). Kalu's (2010a) concern is also a matter of global concern. According to the World Report on Violence and Health, violence is seen as a major and growing health problem across the world (Krug et al. 1996:1083-1088). Unfortunately, women and children are the most affected victims. They experience emotional, physical and psychological trauma as a consequence of such violence. This is because violence is often perpetuated in contexts of power imbalance, limited choice and abusive intimate relationships (Campbell 2002:1331-1336). Therefore, combating poverty, gender inequality, child mortality and poor maternal health and promoting disease education ${ }^{1}$ and partnerships for development are paramount in the United Nations' formulated goals (Millennium Development Goals n.d.). This socio-economic situation in Africa clearly shows a

1.The term commonly used is "health education', which includes improving the understanding, detection and management of disease. 
dialectical relationship between poverty, ill-health and underdevelopment. However, in the face of the challenges of ill-health, poverty, underdevelopment and violence, religion has provided a source of strength for Africans. Recent studies have identified a connection between health, religion and spirituality (Cobb, Puchalski \& Rumbold 2012; Koenig, King \& Carson 2012). Such connections are found to sometimes implicate religion negatively, but more often than not religion has been connected to positive health outcomes (Bompani 2015:101-113; Cochrane 2010:175-196; Lipsky 2011:25-36).

\section{Religion as social capital for development}

The notion of religion, as used in this article, implies an institutionalised and organised system involving prescribed beliefs, practices and rituals related to God and the supernatural that engender absolute trust, comfort, hope and dependency in people and community in their search for meaning and purpose. In considering religion, the broader concept of spirituality is also maintained. In this relationship, religion and spirituality are not mutually exclusive terms. Scholars are in agreement that they can be conceptualised as identical, as subdomains of each other, as entirely separate domains or as unique domains that potentially overlap. In this article, religion as a narrower construct is not used as distinct from the wider category of spirituality as some Western definitions often imply. This is because, as has been argued elsewhere, the African understanding of the two concepts is inextricably linked (Agbiji 2013:34-36; Agbiji \& Landman 2014a:n.p). In essence, there is no religion without spirituality and there is no spirituality without religion.

Social capital has been conceptualised in a variety of ways and has different meanings acccording to its purpose and context. Scholars from the different fields of development, theology, healthcare and sociology have a constellation of ideas about this concept. These ideas suggest individual and group resources such as skills, which are harnessed for mutual care and benefit within a network of relationships. These relationships in turn are strengthened by norms and values such as trust and eagerness to engage in forms of care that enable the society to function effectively (Wepener et al. 2010:73). Eigelaar-Meets, Gomulia and Geldenhuys (2010:48) claim that the essence of social capital is the fostering of social inclusion that hinges on a people-centred development approach: such an approach 'provides an increased spectrum of choices for people and broadens their opportunities through their participation in networks'. The notion of social capital acknowledges the fact that individuals desire to make their own choices in life, but they (especially the poor and marginalised) are unfortunately often denied such opportunities. This means that the absence of social capital results in poverty (Wepener et al. 2010:64). Cochrane (2010:182), therefore, argues that the resources of social capital carry value for health. He terms the religious dimension of social capital for health 'religious health assets', which he claims provide a support base for health interventions. The role of religion as social capital in the African context has also been well argued by scholars like Ter Haar and Ellis (2006:351-367), Adogame (2013:107), Eigelaar-Meets et al.
(2010:6182), and Wepener et al. (2010:61-82), to mention a few. Within medical science, the role of religion in medicine and the establishment of modern hospitals in many countries have likewise been well documented by scholars (Cobb et al. 2012; Koenig et al. 2012).

It is important to observe that religion has not always been considered social capital. The understanding of religion as social capital for health and well-being in development discourse is a recent consideration, as religion in the past was often negatively associated as an obstacle to health and development. The relationship between religion and development in Africa was conceived as antithetical to people's development; religion would eventually become obsolete as Africa developed (Bompani 2015:101). The potential benefit of religion was hardly considered (Olivier 2015:347). Such a negative relationship brought about the separation of religion and the state, as governments and research and development organisations increasingly became concerned with science that prejudiced religion during the age of enlightenment, modernism and secularisation. It is no wonder, then, that Lipsky (2011:25) has observed that despite the growing recognition of religious capital in recent literature, international organisations have been reluctant to work with religious organisations, partly on account of this state of separation and partly on account of the fact that most international organisations lack the mechanisms needed to work with the diverse religious capital.

Undeniably, religion must accept its fair share of the blame, as it has at times presented itself negatively as a political tool for manipulation, conflict, corruption and the exclusion of people from society (Ott 2007:169-170). For example, the recent kidnapping of schoolgirls, killings and destruction of property by the Islamist fundamentalist group Boko Haram in Nigeria, the destructive activities of Al-Shabaab in Kenya and Somalia, and other Islamic militant fundamentalist groups in Africa have impacted negatively on people's development (Anonymous 2012:119-120; Harnischfeger 2014:43, 47, 51). It is therefore no wonder that Bompani (2015) has observed that:

[ $r$ ] eligious institutions may not always have been positive influences, and ... [religion] might not always lead people to a path of transformation and emancipation and may in fact lead to greater dependence and poverty. (p. 107)

This negative association of religion with violence and underdevelopment depicts the downside of religion as a resource of social capital.

Therefore, it might be patronising and risky to conceptualise the role of religion in social capital formation only in terms of positive value content. Such an effort is not only misleading but could risk objective reasoning and engagement. In view of the ambivalent role of religion, it is more helpful and meaningful to conceptualise it using specific categories rather than generalities. Rather than making generalised claims, specific questions could be posed as to the extent to which religion can foster social inclusion, purpose and meaning. Who might adequately foster such positive roles? How might 
such roles be sustained? Such specific questions might enhance appreciation of the positive role of religion. One way of appreciating religion as a social capital resource for development is to utilise the perspective of pastoral care.

\section{Pastoral care as development}

Pastoral care, as conceptualised in this article, is both a practice and a discipline. As a practice, it is a reflective practice of faith in everyday life in circumstances of sickness, suffering and pain as direct and/or indirect consequences of inordinate power and unjust socio-economic, political and cultural systems exerting control over people's lives (Agbiji 2013:11; Miller-McLemore 2012:6). As a professional discipline, pastoral care deals with the above-mentioned issues and refers to the intention of human action and the meaning derived from such involvement in life issues, which consequently could affect the quality of life and dignity of the human being in the relationship. It is a task that is carried out by the whole community as directed by professional individuals.

Clinebell (1984:34) argues that pastoral care entails the development of persons and groups towards maturity in character and faith by virtue of its association with human concerns. This association with human concerns gives pastoral care a complex and dynamic character challenged by ambiguities in a situation of mutual need and mutual responsibility. The ambiguity of pastoral care implies that it is not a given that the care rendered by pastoral caregivers will always be effective and helpful. It has the potential to harm and disempower. Moreover, it has a tendency to manipulate and collude with injustice, just as it has the power to heal, restore and transform. For this reason, effective pastoral care carried out by trained pastoral caregivers must demonstrate dynamism by being sensitive, responsible and committed to assisting persons to experience wholeness and well-being. Such dynamism requires pastoral care to review its approaches to religious and spiritual care by giving attention to definitions and self-understanding, practices, sources of authority and cultural and global factors that affect care.

Although pastoral care is hardly articulated as development in the strict sense of the word, we believe that there is a relationship existing between pastoral care, development and social capital. Our conceptualisation of pastoral care as the development of people coincides with the people-centred theory of development. ${ }^{2}$ The essence of African development, according to Agbiji (2012:276), is that it is geared towards responsible well-being, social empowerment and the transformation of people within interconnecting networks of human relations for collective actions. It also corresponds with religious capital formation. Religious capital, as articulated by Adogame (2013:107), comprises an investment or contribution made in time and work by people to religious organisations to improve social life. Such religious capital is

2.Pastoral care and people-centred development overlap to the extent that both disciplines highlight the goal of fostering well-being of persons, although with different epistemological and foundational foci. Therefore, in our understanding pastoral care is distinct from the ideas of people-centred development primarily in its theologica foundation of engagement, this foundation is tied to the mission of God (Agbi) 2013:158-162). Pastoral care participates in empowerment and development action (to influence, change, renew, comfort, sustain and heal) as God's mission to the world. achieved by means of the ability of faith organisations to establish and strengthen the relationships, norms and values known as 'spiritual capital'. In effect, 'spiritual capital energises religious capital by providing a theological identity and worshipping tradition, but also a value system, a moral vision and a basis for faith' (Adogame 2013:107).

Pastoral care as religious capital and spiritual capital for development underscores the fact that human beings have inherent worth and value that transcends many situations and promotes their own empowerment. Empowering them accordingly means to help them to see new possibilities. In the healthcare context, development may entail equipping patients with the necessary life skills to pose the right questions, make the right decisions and adopt an approach that can assist them in their journey towards a more meaningful life and quality care. The underlying assumption is the belief that people are capable of changing positively in relation to growth, no matter how debilitating the circumstances might be and even if they might not be aware of their potential (Clinebell 1984:34; Crichton 1990). Therefore, Louw (2008:76) as such argues that pastoral care equips people with skills to be imaginative, creative and anticipatory towards life and its attendant challenges. The implication for pastoral care in the healthcare context is that the practice of empowerment through reconciliation helps to transform the powerless or sufferers for a better life by making them agents of change and not mere victims.

Attending to issues of development also makes it evident that not all people who visit the hospital are medically sick; they may be there for other reasons (such as regular check-ups, medical examinations, training or in support of family members and friends). The developmental, growth and empowerment models of pastoral care and counselling seek to assist people to discover and use the special features of their particular life stage (Clinebell 1984:128). This suggests that pastoral care involves a general act of caring by all members of the religious community as a ministry of service. ${ }^{3}$ It emphasises availability, compassion and presence to the weak and vulnerable from all members of the faith community. It is also in this regard that pastoral care serves as a resource for religious and spiritual capital for development.

The different development components inherent in pastoral care highlight the value of pastoral care as a resource for health and also for spiritual and social capital for development of people and communities. Thus, Agbiji and Landman (2014a) attempt to establish pastoral care as a resource for health and healthcare both in Africa and the global context.

\section{Pastoral care in the global healthcare context}

The three cardinal goals of health systems are better health, fairness (including prompt attention and access to social

3.This is on the basis that all members of a faith community at the very least, have the gift of grace that enables them to minister to themselves, others and society at gift of grace that enables them to minister to themselves, others and society at
large. Such a gift of grace is sharpened to provide intentional and efficient services by the trained pastoral caregiver. 
support networks) and responsiveness to people's expectations regarding health (WHO 2000:23). According to the WHO (2000:23), responsiveness 'reflects the importance of respecting people's dignity, autonomy and the confidentiality of information'. Responsiveness also implies that 'people have expectations which the society regards as legitimate, such as how they should be treated, both physically and psychologically. Responsiveness is therefore a social goal.' Guided by this principle, the WHO (2000) declared most health systems in the world to be poor. Moreover, in a later document, the WHO (2010) declared that a well-functioning health system responds to people's needs and expectations by improving their health status and (among other things) involving them in decision-making about their health and healthcare (WHO 2010). In this regard, the WHO (2000) notes that virtually all countries are under-utilising the health resources available to them.

One of the resources that is underutilised is the religious and spiritual resource of pastoral care, which constitutes a potentially unique social capital resource for health and healthcare for many people in the world. It is increasingly accepted that Africans everywhere in the world are intrinsically religious or spiritual (Adogame 2013:123). To be responsive to these patients is to give dignity to their religious and spiritual value of healing by making it accessible to them during crises of illness and hospitalisation. Puchalski et al. (2006) argue that:

[S]piritual care supports the dignity of each patient by honouring inherent beliefs and values that support them and their practices that enable them to find meaning and hope in the midst of suffering. By being attentive to the spiritual dimension of people's lives, we believe that care becomes compassionate and whole. (p. 400)

However, a purely classical model of healthcare does not take the religious category into consideration. Such neglect could engender resistance and distrust from care seekers. It has been argued elsewhere that although people are open to the forces of change regarding their healthcare, they will also fight to retain their religious and spiritual identity, which they consider valuable and unique to their identity and dignity (Agbiji \& Landman 2014b).

The concern for religious and spiritual resources as part of an interdisciplinary vision for healthcare has started to receive global attention among researchers, policymakers and practitioners in healthcare, pastoral care and other related fields (cf. Kestenbaum et al. 2015; Puchalski et al. 2006). At the same time, however, the role and identity of pastoral caregivers differ from one healthcare context to another. In some contexts, like those in the USA and Europe, creating a space for pastoral care in the hospital context is currently an urgent debate (De Vries-Schot et al. 2008). Such debates centre on issues that pertain to the inclusion of pastoral caregivers in the interdisciplinary medical team for the purpose of collaboration and consultation (McClung et al. 2006; VandeCreek 2010).

It is worth noting that the concerns and debates on pastoral care are not an end in themselves in European, US and
Australian contexts, but a means to the goal of incorporation as evidenced in healthcare policy reforms and practices. Orton's (2008:n.p) careful exploration of best practices in research on pastoral care in hospitals in the USA, UK and Australia indicates that pastoral care in these contexts has been given serious consideration in healthcare policies and practices; therefore, 'evidence supports the inclusion of pastoral care in the holistic health care' in these contexts (Orton 2008:n.p).

Consequently, the governments of these countries have produced guidelines and policy documents on the provision of pastoral care. The demand for such policies has led to the establishment of several professional and regulatory bodies for pastoral care as well as centres for training both professional and volunteer pastoral and spiritual caregivers in clinical pastoral education (CPE), for example Orton (2008:n.p). Most importantly, centres for research in spirituality and health interface [e.g. The Canadian Research Institute of Spirituality and Healing (n.d.); The George Washington Institute for Spirituality and Health (GWish) (n.d.)] have also been established. These institutions state as their mission the establishment of a more compassionate and integrated system of healthcare by promoting and restoring the heart and humanity of medicine through research, education and policy work focused on bringing increased attention to the spirituality, culture and healing of patients, their families and healthcare professionals.

The Joint Commission on Accreditation of Healthcare Organisations, a major healthcare regulatory body in the USA, has introduced the inclusion of spirituality and pastoral care into the clinical setting in their healthcare policy (Sakurai 2003:27). The need to meet the accreditation criteria of this regulatory body contributes to the integration of pastoral care and the employment of pastoral caregivers in hospitals. Such requirements also imply that spiritual and pastoral care services in healthcare institutions should be effective, efficient and professionally accountable (Sakurai 2003:27). The impact of the policy and centres for spirituality and health is evident in the incorporation of spirituality into the curricula of more than $75 \%$ of the medical schools in the USA. In a recent newsletter (About GWish n.d.), the director of the GWish centre, Dr Christiana Puchalski, comments:

The integration of spirituality into our medical culture is crucial for creating compassionate, patient-centered physicians. It changes our health system from merely emphasising physical suffering. Rather, physicians are taught to respond to all patients' suffering with compassion, recognising that health is more than the absence of disease. This is when healing [which is defined] as a patient's ability to find hope and meaning even in the midst of suffering occur[s]. (n.p.)

Tovino's (2005) review of current hospital policies and procedures demonstrates that many hospitals in the USA perceive pastoral care as an essential component of healthcare and the pastoral caregivers as members of the healthcare team. Based on her research on the functions of hospital 
chaplains in US hospitals, Tovino describes the role of hospital pastoral caregivers as follows:

As part of their job hospital chaplains [pastoral caregivers] interact with patients and families, medical and nursing staff members, ethics committees and institutional review board members, hospital administrators, volunteers, and community members. (2005:69)

When we look at the European context, the history of healthcare and religion indicates that pastoral caregivers have always been part of hospital care. ${ }^{4}$ Modern healthcare in Europe (e.g. in the UK) is centralised, publicly funded and dispensed by the National Health Service (NHS) (Orton 2008:n.p). Pastoral care has been part of the NHS initiative from its inception. This helps professional caregivers to be listed as part of the interdisciplinary healthcare team under the NHS (Cobb 2005:13). In the UK, funding for pastoral care is more directly part of the NHS policy (Orton 2008:n.p), following the NHS Reform and Health Care Protection Act of 2004. This is because the NHS considers meeting the pastoral care needs of patients, staff and visitors fundamental to the care it delivers. The resulting effect is the development of an integrated national service standard and education and training that is patient-centred (Kofinas 2006:671); this includes meeting the religious and spiritual needs of patients. According to Kofinas (2006:671), this standard ensures the professional and scientific quality of pastoral and spiritual care as well as the protection of patients from unwholesome pastoral caregiving.

In Australia, the Policy and Funding Guidelines for Mental Health Services 2008-10:

explicitly indicates that public health services and public hospitals are to ensure that mechanisms are in place to enable the diverse religious, pastoral and spiritual care needs of patients are met.' (Orton 2008:n.p)

This policy applies despite the fact that Australia is essentially a secular state. The above-mentioned practices and integration of pastoral care, which are not only at the level of practice but also at the policy level, may represent best practices for the utilisation of the religious and spiritual resource of pastoral care in healthcare institutions. In line with the practical theological lens of the normative task of good practice, as enunciated by Osmer (2008:147-152), good practice for normative reflection as drawn from contexts such as Europe, North America and Australia and the WHO could assist healthcare systems in Africa to generate new insights with which to (re)organise pastoral care by learning from the gains and/or mistakes of such traditions. According to Osmer, models of good practice assist organisations to creatively engage in acts of care to produce better or different results. In this regard, they could provide resources and guidelines for practice (Osmer 2008:152-153) with necessary adjustments that could address some peculiarities that relate

4 in the African context, South Africa comes close to the US and European contexts in the contempory provision of pastol care in the hosptal with efforts made to the contemporas provision of pastoral care in the hospital with efforts made to establish the association of pastoral workers that see to the registration and accreditation of pastoral caregivers. However, such pastoral work is yet to be recognised in South African healthcare policies as legitimate practices (Smit 2015:1) to the African context. These global practices that constitute good practice in healthcare have valuable implications for Africa's healthcare delivery system.

\section{Implications of global trends in pastoral care for Africa's healthcare delivery system}

Several implications can be drawn from the global trends in pastoral care that are relevant for Africa. The latter would benefit from pastoral and spiritual insights, inspiration and practices from the global scene as a vision of best practices, according to Osmer (2008:153). This is because the beginnings of hospital pastoral care in the North American, European and Australian contexts reveal a similarity with the African context in terms of the background and history of medical and pastoral care practice. However, the common and shared visions of both pastoral care and medical care have changed significantly over the years. For instance, health systems as operated today in Africa are marked by the Western colonialist approach to healthcare, which disregarded the interconnectedness of health and religion that characterised the African worldview. In so doing the colonialists imposed a secularised and fragmented worldview of illness, which also greatly undermined the holistic and religious understanding of illness and health in Africa (Agbiji 2013:40-60; Akinyemi 2006:287). This understanding of illness, behaviours and healing approaches among Africans is rooted in and influenced by Christianity, Islam and African traditional religion (Nagamia 2003:20).

It is an established fact that healthcare and pastoral care practices in Africa, as is the case elsewhere in the world, are supported by cultural values about what constitutes illness and health. In other words culture, religion and health are so intertwined that attempts to separate them often result in a care that is alien to the desire of Africans for health. In effect, many Africans do not perceive pastoral care and healthcare as mutually exclusive practices. However, healthcare systems as run by African governments still separate health from religion, a vestige of the colonial enterprise. Meanwhile health institutions in the West, such as in the North American, European and Australian contexts discussed above, could be said to have progressively moved from a strictly medical model that privileged a compartmentalised healthcare that separated medicine from religion. It is progressively embracing the now so-called biopsychosocio-spiritual model, where pastoral care (both in its parochial and specialised forms) is gradually being considered as part of a dynamic and holistic standard process of healthcare (De Vries-Schot et al. 2008:104). This is in response to the global healthcare crisis, which requires an approach to healthcare that takes into consideration all the intricacies of illness, as well as the changing contexts of healthcare as directed by global interactions, research, reports and policy formulations. Regrettably, most formal healthcare systems in Africa as officially practised and documented in policies and medical codes of ethics are still steeped in the classic biomedical 
model (cf. Code of Medical Ethics in Nigeria 2004; Africa Health Strategy 2007-2010[2007]). This classic biomedical model persists despite evidence gleaned that the preference of many African patients is to consult a pastor, a doctor and even a traditional healer (Unuhu et al. 2009:24). Such eclectic utilisation of healing methods may suggest a desire on the part of African patients for the incorporation of spiritual care into their medical treatment plan. In some instances nurses and doctors have acknowledged such desires by posting on the walls of their offices that, whereas they treat illnesses, healing truly comes from God. ${ }^{5}$

Whereas most healthcare systems in Africa have been declared weak, hindering the journey towards the attainment of the Millennium Development Goals (Africa Health Strategy 2007:2; Olivier \& Wodon 2012:821; WHO 2000), there is a growing recognition by many African governments, health policymakers and researchers of the need to strengthen health systems in order to deliver efficient and effective health interventions (cf. Africa Health Strategy 2007; National Planning Commission 2011; National Development Plan 2030 [2011] of South Africa; Federal Ministry of Health, National Strategic Health Development Plan [NSHDP] 2010-2015 [2010] of Nigeria). In effect, many African governments are presently engaged in healthcare reforms, regulation and policy formation to improve quality, medical equipment, human resources, planning and development. There are also claims of African governments' increasing interest in faith-based health services and the willingness of such governments to collaborate with faith organisations for health service delivery (Olivier 2015:352; Olivier \& Wodon 2014:21). Examples are the invitation by President Zuma of South Africa of religious leaders to strategy meetings and consultations (Bompani 2015:101), as well as the much-cited involvement of the World Council of Churches in forging pathways for primary healthcare (Cochrane 2010:178; Rookes \& Rookes 2012:837). Such attempts have not resulted in any policy transformation regarding spiritual care provision in African healthcare. Disappointingly, the reforms and regulations are not reflected in policy statements on the provision of religious, spiritual and pastoral care - unlike in the USA, UK and Australia as discussed above (cf. Africa Health Strategy; NSHDP 2010-2015 of Nigeria, NDP 2030 of South Africa).

The exclusion of pastoral and spiritual care from African healthcare systems may imply that the religious leaders did not pay enough attention to African people's desire for

\footnotetext{
5.This position was gathered from interviews by the authors with some Nigerian nurses, doctors and pharmacists in selected teaching hospitals in Nigeria on their opinion on the incorporation of pastoral care(givers) into the medical team in 2010. Whereas all the medical professionals the authors chatted with indicated that professional pastoral care that is well informed is a welcome idea and could assis the medical professionals in determining the treatment plan and the healing or recovery process of the patients, it is not incorporated into the plan because spiritual care is not incorporated into their training and also because the medical code allows no room for such incorporation. Consequently, some medical staff who are favourably disposed to such spiritual approaches allow the patients to call their pastors to minister to them whenever possible. After the visit of the pastor th medical personnel may discover that the patient has become more cooperative more hopeful and more at peace. In some instances, they may find that the patient rejects the medical treatment, thereby causing difficulties. As a result of such rejects the medical treatment, thereby causing difficulties. As a result of such negative outcomes some of the medical professionals are more comfortable with a situation where a member of the medical staff carries out such pastora responsibilities whenever possible. However, such staff are also at risk. Such practice is risky because it is not an acceptable practice and if a fellow staff member who is not favourably disposed to the spiritual process decides to pursue a case of unethical practice, such staff will be disciplined (Interview with a medical practitioner at a teaching hospital in Nigeria, December, 2010).
}

spiritual care during such meetings and consultations with governments (as mentioned above) or that their contributions were simply ignored by African governments and medical practitioners. Whereas African health reformers pledge to regularly review their health policies to ensure that they are up-to-date reflections of those governments' visions and priorities, that they reflect best practices and take into account the realities and socio-cultural circumstances of their respective countries (Africa Health Strategy 2007:7), these reforms have in actual fact not lived up to these promises. Therefore, these reforms and healthcare policies, which often direct the provision of healthcare and are used as benchmarks for quality care, in our opinion have not taken account of the health behaviours of Africans and their desire for health, which also includes spiritual care as complementary and alternative medicine (CAM). CAM may represent an informal health system approach.

A meaningful reform of healthcare systems in Africa should combine both formal and informal components of health systems. As it stands, the policies and reforms do not do justice to the continuing importance of religion in many African communities. This implies that African governments may have an agenda that undermines the culturally acceptable means of health provision for many people, and by implication the human dignity of patients (Agbiji \& Landman 2014b; Bompani 2015:101-102). To some extent, this may suggest that the religious component is not considered significant for healthcare in clinical settings. Thus, pastoral care is left to the discretion of each medical practitioner. Healthcare practitioners who integrate pastoral care in their patients' care do so at their own peril because they are not adequately protected by policy. This is because such integration may be viewed as an unethical practice by those who hold tenaciously to policy statements. Thus, the provision of pastoral care in clinical settings in Africa is often an issue of contention. On the issue, Kalu (2010b:201) has clearly observed the deep apathy that religious practices of care receive from medical, psychological and psychiatric professionals. As he observed, such apathy is rooted in Africa's embeddedness in the Western worldview, which is more concerned with disease than the meaning and impact of the disease on patients' values and identity. However, as has become evident, Western contexts are reviewing and moving away from their negative stance regarding religion and spirituality in healthcare.

On another level, this state of affairs in Africa also presumes that the issue of pastoral care in healthcare institutions has not generated sufficient debate and research within the African academic community to give policymakers and governments confidence for the inclusion and integration of religious and spiritual caregivers in the interdisciplinary healthcare teams of African healthcare systems. This may also mean the non-development of professional pastoral caregiving in healthcare institutions in Africa. This may imply that pastoral care in Africa has yet to address broader issues of justice and equity that are not limited to the religious 
community but that affect the wider society, like healthcare institutions (Neethling 2003). Research in provision of pastoral care remains limited and marginal. Where the contribution of religion to health has been researched, it is often based on the experience of faith-based organisations focused on the provision of tangible health assets such as infrastructure, healthcare personnel and the provision of drugs. Faith-based intervention in terms of provision of pastoral and spiritual care has hardly been the focus of such religious contributions (cf Bompani 2015; Lipsky 2011; Rookes \& Rookes 2012). The reason religion in healthcare is given such superficial attention becomes immediately evident when we realise that these scholars are from the disciplines of public health and development studies. Olivier (2015:346) also observes that until 2005, 'there was no available information on the presence and contributions of religion to healthcare in development context'. As a result, religious institutions' contribution to health was excluded from the WHO's Service Availability Mapping (SAM) and assessment systems. The non-visibility of the religious contribution to health by extension means the non-visibility of pastoral care (givers) as a vital health resource. It also means that research on religion is done using a certain epistemological frame that minimises the role of religious, spiritual and pastoral care in healthcare.

The disciplinary and epistemological bias in health policy research on religion easily becomes evident in the work of Olivier (2015:352), Olivier and Wodon (2014:820-821) and Lipsky (2011:26). Their research helps to explain the absence of religious provision in African health policy. They credit the non-inclusion of religion in African healthcare policies to a number of factors, such as the difficulty in researching the contribution of religion because of the varied terminology used to describe the term and because religion is not properly aligned with national health systems. Although this might pass for a cogent explanation for non-conclusion, one might question whether this posture is in concert with the African worldview. For instance, when Africans go to the clinic and are, for example, given paracetamol, what questions are they likely to pose regarding the paracetamol? Would these be about defining and describing the content of the paracetamol? Or would these more likely be about whether it will meet their health needs? Attempts to do research in the religious category are often substandard, with data frequently absent or incomplete on the significance of the faith factor in the improvement of health and development. Other reasons are that coordination among researchers is often lacking and that information and results are often not made public. The reluctance to include religious factors in health policy may also mean that a vital health resource for preventing and reducing the disease burden (e.g. of HIV and AIDS) and for health promotion is largely being neglected (Agbiji \& Landman 2014a:1-11; Olivier 2015:352). Increasing the visibility of pastoral care resources to development and healthcare policymakers requires more robust research on pastoral care. However, such research needs funding that is not often accessible to pastoral theologians. Thus, such research, as rightly posited by Olivier (2015:353), will benefit the field of development and health by focusing on health policy and health system research that favours multisectoral collaboration. This does not necessarily need a unified terminology or a common language as a prerequisite for interdisciplinary research. In addition to Olivier's suggestion we would suggest that such research into the African reality of health must include researchers of African descent as well as pastoral theologians who are able to bring the unique perspective of the African to the fore.

Dealing with issues of pastoral care in the African healthcare context at the level of research and practice may raise several questions. Taking the religiously pluralistic nature of African societies into consideration, pertinent questions may arise such as how pastoral care intends to navigate the religious diversities of Christianity, Islam and African traditional religion in such public spaces. For instance, can pastoral care be invoked for Muslims and patients who follow African traditional religion?

It is worth emphasising that pastoral care is a broad concept that has been used in different traditions (Isgandorova 2005:85). The fact that the term is being used extensively by the Christian church does not necessarily make it exclusively Christian. Like Christianity, Judaism, Islam and African traditional religion have also exerted much influence on healing methods among Africans, supported by cultural beliefs and values about what constitutes health. Such influence makes linkages between the physical, spiritual and medical dimensions of care in Africa and blurs the healing practices. This blurring allows the sick to select eclectically from whatever practitioners were available to them. These eclectic practices suggest the pervasive nature of healing, which transcends religious boundaries and space. In many instances traditional healers have been reported to belong to churches and some have even become pastors. In contrast there are some pastors who also are traditional medicine men or women (Phiri 2006:120-121). Phiri's (2006:120-121) research on sangomas in South Africa leads her to the conclusion that in many African families, Christianity and African indigenous religion coexist and that there exists in many instances a free flow of beliefs and practices between the two religions. This may suggest that a Christian perspective of pastoral care would not be an issue, especially for the indigenous African traditionalist. This is because traditional religion is not by nature a missionary religion, which may explain why both religions could stand in solidarity and communion with one another (Lekwata 2003:183). However, on the part of African Christians such eclectic practices are often viewed as syncretistic and often attract contention, suspicion and negative feelings. When the issues of Muslims are introduced it further highlights the complexity of the situation.

This eclectic approach to illness and solidarity with one another during illness by many Africans highlights an important consideration, as well as pointing to the limitations 
of pastoral care in the multireligious space of the hospital. Yet where these practices among the various religions are devoid of contention, they highlight the fact that in many African communities spiritual care and healthcare are not mutually exclusive terms and are carried out everywhere - in shrines, homes, markets, healing homes, churches, mosques and so on. Given this background, pastoral care must be sensitive in taking into account this African religiocultural worldview of solidarity and communion that breaks boundaries of religion, place and time. It must be carried out beyond the confines of the church, mosque and shrine and should extend to the hospital space as an authentic expression of spiritual care. Such caregiving must be provided to all who desire it while remaining sensitive to the diversity of people from the different religious and denominational affiliations.

Questions might therefore be raised as to whether pastoral care is capable of fulfilling such an ambitious role of meeting the spiritual needs of all. How would a pastoral caregiver carry out his or her responsibilities to all without overstepping boundaries? Could such caregiving be trusted and effective? In other words it calls into question the limits and possibilities of pastoral care. Wrestling with these questions, we would like to consider two possibilities. One possibility would be what pastoral scholars have termed the 'parochial approach'.

This approach refers to the traditional delivery of pastoral care, in other words pastoral care along denominational and religious lines delivered by a Christian to a Christian, Muslim to a Muslim, or traditionalist to a traditionalist. By definition, the parochial approach to pastoral care refers to the provision of pastoral care by those who have not had professional training in hospital-based pastoral care but who volunteer their services on a part-time basis within the confines of their particular denominational representation of their particular religious group (Orton 2008:n.p). The purpose of this approach to pastoral caregiving is often characterised by proclamation, deliverance from sin and a desire to sustain their denominational members. In this regard, the pastoral caregiver places the sharing of God's message at the centre of his or her care. For this reason many denominations term their pastoral caregiving in hospital 'hospital evangelism'. This approach is often criticised by scholars as possessing an exclusivist character, 'unaccepting of the religious and moral claims of others' (Engelhardt 2003:148; Schmidt \& Eglar 1998:248).

While this approach to pastoral care might have some benefits, such as opening the space for mutual care where skills are not emphasised, its focus on proselytising reveals fundamental challenges. It enforces amateur practices that hinder meaningful professional engagements and collaboration with other faith groups and development agencies (Engelhardt 2003:148; Lipsky 2011:32). Rookes and Rookes (2012:837) are concerned that some evangelical denominations continue to see healthcare provision first and foremost as an opportunity for proselytisation rather than a tangible profession of their faith. This approach to pastoral care is often a point of concern for development and healthcare professionals and raises questions as to whether pastoral care that is operated in this narrow way displays enough sensitivity to the vulnerability and powerlessness of the sick and whether indeed it can be utilised as a religious resource for development. These flaws inherent in the parochial model demand consideration of a second approach, namely the professional model.

Professionalisation and specialisation of the ministry of pastoral care in the healthcare context has become necessary in the African hospital space because of the highly technical and professional context of healthcare. Thus, pastoral care in the healthcare context will have to embody a dual identity as a calling as well as a profession. Such professional identity requires special knowledge, skills and dedication that contribute to a more competent and greater service of God and the people than the parochial approach that prevails at present (Agbiji 2013:226-227).

Professional pastoral care requires a move away from denominational caregiving of patients by their own caregivers to the provision of spiritual care to the public at large, irrespective of denominational affiliation (this would include non-believers) (Orton 2008:n.p). With this mission in mind, protecting patients from aggressive proselytising in the face of sickness, suffering and vulnerability is the goal. In this way the professional approach, unlike the parochial approach, goes beyond mere healing and solidarity and takes up issues of advocacy, liberation, development and empowerment. The professional drive seeks to transcend the fragmentation threatened by denominational commitments (Engelhardt 2003:153; Lipsky 2011:32). This approach embodies inclusive care, which reflects the kingdom of God as the context and foundation of pastoral care to the sick in the hospital. It promises to be useful particularly in contemporary African society, where different religions struggle for supremacy over others, giving rise to religious tension and even violence and terrorism.

In view of the desire to provide holistic care to all, there is a strong trend in favour of pastoral caregiving that prioritises the interfaith ministry. Interfaith practices are based on the clinical and intercultural paradigm of pastoral care that acknowledges the contextual complexities of care in the healthcare setting. The interfaith approach in pastoral care advocates the principle of 'common ground' as the means of providing effective and adequate care. Such common ground recognises that patients in hospital are in a similar situation and have common grounds that may permit their being accompanied in their quest for meaning (Agbiji 2013:227). The common ground can also be employed through rituals.

The downside of professional pastoral care can be identified in the tendency to narrow care of the sick to specialised individuals. A major setback could be a tendency to be detached from religious and denominational affiliation, raising questions of identity and basic theological and theoretical orientation. This downside could be minimised by the development and training of laypeople, volunteers 
and religious denominational representatives such as that provided by basic training in CPE programme liturgy and diaconal service for lay volunteers (Agbiji 2013:227).

Operating from an interfaith perspective requires the pastoral caregiver to recognise the limits of interfaith cooperation. The pastoral caregiver does not need to give up or hide his or her own identity (e.g. a belief in Jesus Christ as the saviour) in order to be respectful to the patient's religious path when ministering to patients of other faiths. Bueckert (2009:148) warns that 'engaging in the interfaith spiritual care caregiving therefore does not require that we give up our convictions, though they may be challenged'. Respect means recognising and acknowledging the other's differences. Identifying with the belief of one's own faith is an essential element of religious identity. According to Schneider-Harpprecht (2003:98), ignoring one's background could amount to self-exclusion from one's own faith group and could even contribute to that group's destruction. Schmidt and Egler (1998:252) insist that 'respecting other religion while maintaining one's own religious identity entails the acceptance of certain limitations for inter-religious pastoral care'.

To attain the desired level of integration of pastoral care in Africa's healthcare institutions, policies and practices, as well as to recognise healthcare practitioners as a valuable resource of social, religious and spiritual capital, as in some of the developed countries, requires research on healthcare systems. Such research, it is suggested, should be carried out in all relevant disciplines taking into consideration best practices from other contexts. This means that health institutions, practitioners, governments, policymakers and pastoral caregivers must also become aware of global trends and be part of the global discussion.

\section{Conclusion}

The task of this article from the beginning was to make a case for pastoral care as a resource for development within healthcare systems in Africa. We noted the insufficient attention given to pastoral care in healthcare policy research and planning. Nonetheless, pastoral care is essential for the well-being and holistic development of African people and communities. The absence of pastoral care in healthcare in Africa is obvious, despite the increasing recognition of religion as religious and social capital for development by government and development research in Africa and elsewhere. Thus, we ventured to question the reasons for the limited attention given to pastoral care.

The quest for possible answers demanded that we approach the study from an interdisciplinary perspective. The interdisciplinarity of the study was therefore grounded in a practical theological frame from the normative stance of good practice as formulated by Osmer (2008). Osmer's methodological framework provided direction for this article and assisted us to explore pastoral care in healthcare institutions in the global context and to draw implications for pastoral care in healthcare systems in Africa. As Osmer conceives it, utilising good practice for normative reflection helps to generate new insights with which to (re)organise practice by learning from the gains and/or mistakes of other traditions. In the end, it provides resources and guidelines for practice (2008:153).

In other words, to understand and appreciate the ongoing socio-economic reality of Africans and the impact on their health and development, we explored the health conditions in Africa and the quality of healthcare on the continent. The exploration showed that African people and communities are saddled with a heavy disease burden and poverty, rendering the quality of their healthcare inadequate. However, the exploration also showed that religion provides a source of strength for most Africans, highlighting a strong connection between health and religion and pastoral care. Attending to the needs of persons in such debilitating conditions draws attention to pastoral care as fundamentally fostering wholeness towards the transformation and development of persons. Such understanding underlines the potential of religion (notwithstanding its potential weaknesses) as social capital and pastoral care, providing religious and spiritual capital for development. Such articulation hinges on pastoral care as having the potential to harness individual and group resources, such as norms and values, which can be engaged for mutual care and benefit within a network of relationships. This informs the drive towards providing professional pastoral care that is geared towards efficiency, proficiency and competency. Sadly, the non-consideration of pastoral care in the healthcare policies of African states means that a resource for health and development has been largely excluded in Africa. We note, however, that although all countries are under-utilising their health resources, African countries are performing worse when compared with what is available in North America, Australia and Europe.

The exploration of the North American, Australian and European contexts also revealed that countries within these regions are doing better in harnessing their health resources, including spirituality and pastoral care, into patient care by their regulating organisations. This state of affairs in the global north and in many other parts of the world has implications for African healthcare systems. It calls for a reorganisation of healthcare systems in Africa to include pastoral care in their healthcare policies and regulations. This is a necessity because many Africans do not perceive pastoral care and healthcare as mutually exclusive practices. Neglecting this perspective means that African governments may be following an agenda that undermines the culturally acceptable means of health provision for many of her people and by implication undermines their human dignity. However, the healthcare system is an evidence-based health service that sets basic standards for the members of the healthcare team to fulfil their roles if such roles are to be considered valuable to the team and even to the patient. This research calls attention to the discipline of pastoral theology in Africa to explore the public theological dimension of pastoral care in the area of public health and policy. This entails pastoral care in Africa working towards generating 
more robust research in development and health system approaches and collaborating with other health system researchers to increase the visibility of pastoral care as a resource for development in Africa.

\section{Acknowledgements Competing interests}

The authors declare that they have no financial or personal relationships that may have inappropriately influenced them in writing this article.

\section{Authors' contributions}

E.A. was responsible for the conceptualisation of the title, theme and structure of the article as well as the drafting of the article. O.A. was responsible for the revision and editing of the article.

\section{References}

Adogame, A., 2013, African Christian diaspora: New currents and emerging trends in World Christianity, Bloomsbury Publishing, New York.

Africa health strategy 2007-2015, viewed 1 February 2016, from http://www.nepad. org/system/files/AFRICA_HEALTH_STRATEGY(health).pdf

Agbiji, E.O., 2013, 'Pastoral caregivers in the Nigerian hospital context: A pastoral theological approach', PhD thesis, Stellenbosch University, Stellenbosch.

Agbiji, E. \& Landman, C., 2014a, 'Overcoming fragmentation and waste in healthcare systems in Africa: Collaboration of healthcare professionals with pastoral caregivers (PCGs)', HTS Teologiese/Theological Studies 70(2), viewed 21 July 2015, from http://www.hts.org.za/index.php/HTS/article/view/2654/5109

Agbiji, E. \& Landman, C., 2014b, 'Health and healthcare in a Nigerian historical context', Studia Historiae Ecclesiaticae 40(1), 233-249.

Agbiji, O.M., 2012, 'Development-oriented leadership in post-military Nigeria: A sustainable transformational approach', PhD thesis, Stellenbosch University, Stellenbosch.

Akinyemi, A., 2006, 'African health on sale: Marketing strategies in the practice of traditional medicine in Southwestern Nigeria', in T. Falola, \& M. Heaton (eds.), Traditional and modern health systems in Nigeria, pp. 287-303. Africa World Press, Trenton, NJ.

Anonymous, 2012, 'Popular discourses of Salafi radicalism and Salafi counterradicalism in Nigeria: A case study of Boko Haram', Journal of Religion in Africa 42(2), 118-144. http://dx.doi.org/10.1163/0700666-12341224

Belshaw, D., Calderisi, R. \& Sudgen, C. (eds.), 2001, Faith in development: Partnership between the World Bank and the Churches of Africa, Regnum Book International, Oxford.

Bompani, B., 2015, 'Religion and development in sub-Saharan Africa: An overview', in E. Tomalin (ed.), The Routledge handbook of religion and global development, pp. 103-113, Routledge, New York.

Bueckert, L., 2009, 'Stepping into the borderlands: Prayer with people of different faith', in D. Schipani \& L. Bueckert (eds.), pp. 29-49, Interfaith spiritual care: Understandings and practices, Pandora Press, Ontario.

Campbell, J., 2002, 'Health consequences of intimate partner violence', The Lance 359(9314), 1331-1336. http://dx.doi.org/10.10.16/S0140-6736(02)08336-8

Canadian Research Institute of Spirituality and Healing (CHRISH), n.d., About CRISH viewed 15 May 2014, from http://www.crish.org/index.html

Clinebell, H., 1984, Basic types of pastoral care and counseling: Resources for the ministry of healing and growth, Abingdon Press, Nashville, TN.

Cobb, M., 2005, The hospital chaplains handbook: A guide for good practice, Canterbury Press, Norwich.

Cobb, M., Puchalski, C. \& Rumbold, B. (eds.), 2012, Oxford textbook of spirituality in healthcare, Oxford University Press, Oxford.

Cochrane, J.R., 2010, 'Health and the uses of religion: Recovering the political proper?', in B. Bompani \& M. Frahm -Arp (eds.), Development and politics from below: Exploring religious spaces in the African State, pp. 175-196, Palgrave Macmillan, Basingstoke.

Cochrane, J.R., 2011, 'A model of integral development: Assessing and working with religious health assets', in G. Ter Haar (ed.), Religion and development: Ways of transforming the World, pp. 231-252, Columbia University Press, New York.

Code of medical ethics in Nigeria: Rule of professional conduct for medical and dental professionals, 2004, viewed 4 October 2011, from http://www.elearning. ttree.org/pluginfile.php/34691/mod_folder/content/0/3_2codeonmedical Ethics.pdf?forcedownload $=1$
Crichton, J.D., 1990, 'Nature of pastoral care', in A.V. Campbell (ed.), A dictionary of pastoral care, pp. 188-196, SPCK, London.

Davids, I., 2008, 'The global context of development and its effect on South Africa - A macro approach', in F. Theron (ed.), The development change agent: A micro-level approach to development, pp. 23-40, Van Schaik, Pretoria.

De la Porte, A., 2013, 'Spirituality and health: Towards holistic person-centred healthcare in South Africa', Unpublished Manuscript, University of South Africa.

De Vries-Schot, M.R., Van Uden, H.F., Heitink, G. \& Pieper, J.Z., 2008, 'Healthy religiosity and salutary faith: Clarification of concepts from the perspectives of psychology, psychiatry and of theology', Journal of Empirical Theology 21, 88-108. http://dx.doi.org/10.1163/092229308X310759

Eigelaar-Meets, I., Gomulia, C. \& Geldenhuys, A., 2010, 'An emerging strategy of social capital formation: Opportunity and challenge for the religious sector', in I. Swart, H. Rocher, S. Green \& J. Erasmus (eds.), Religion and social development in postapartheid South Africa: Perspectives for critical engagement, pp. 45-49, Sun Press, Stellenbosch.

Engelhardt, H.T., 2003, 'The deChristianization of Christian hospital chaplaincy: Some bioethics reflections on professionalisation, ecumenization and secularization', Christian Bioethics 9(1), 139-160. http://dx.doi.org/10.1076/chbi.9.1.139.17376

Federal Ministry of Health, 2005, Draft Health Promotion Policy for Nigeria, viewed 21 February 2013, from http://www.fmh.gov.ng

Federal Ministry of Health, Nigeria, 2010, National Strategic Health Development Plan (NSHDP) 2010-2015, viewed 21 February 2013, from http://www.fmh.gov.ng

George Washington Institute for Spirituality and Health (GWish), n.d., About GWish, viewed 15 May 2014, from www.smhs.gwu.edu/gwish

Harnischfeger, J., 2014, 'Boko Haram and its Muslim critics: Observations from Yobe State', in M.P. de Montclos (ed.), Boko Haram: Islamism, politics, security and the state in Nigeria, pp. 33-62, African Studies Centre, Leiden, viewed 22 August 2014, from https://openaccess.leidenuniv.nl/bitstream/handle/1887/23853/ ASC-075287668-3441-01.pdf?sequence=2)

Isgandorova, N., 2005, 'Islamic spiritual care in healthcare setting', in T. Meier, J. O'Connor \& P.L. Vankatwyk (eds.), Spirituality and health multidisciplinary exploration, pp. 85-104, Wilfred Laurier University Press, Ontario.

Kalu, O.U., 2010a, 'Tangled roots in the Mangrove forest: The cultural landscape of political violence in Africa', in W.J. Kalu, N. Waribo \& T. Falola (eds.), Religion in Africa: Conflicts, politics and social ethics, the collected essays of Ogbu Uke Kalu, vol. 3, pp. 291-309, Africa World Press, Trenton, NJ.

Kalu, O.U., 2010b, 'Healing as the children's bread: Contested coping-healing strategies in African Pentecostalism', in W.J Kalu, N. Waribo \& T. Falola (eds.), Religion in Africa: Conflicts, politics and social ethics. The collected essays of Ogbu Religion in Africa: Conflicts, politics and social ethics
Uke Kalu, vol. 3, Africa World Press, Trenton, NJ.

Kestenbaum, A., James, A., Morgan, S., Shield, M., Hocker, W., Rabow, M. et al., 2015 "Taking your place at the table": An autoethnograhic study of chaplains' participation on an interdisciplinary research team', BMC Palliative Care 14(20), participation on an interdisciplinary research team,'
1-10. http://dx.doi.org/10.1186/S12904-015-0006-2

Koenig, H.G., King, D.E. \& Carson, V.B., 2012, Handbook of religion and health, Oxford University Press, New York.

Kofinas, S., 2006, 'Chaplaincy in Europe', Southern Medical Journal 99(6), 671-674. http://dx.doi.org/10.1097/01.smj.0000221752.40522.d0

Krug, E.G., Mercy, J.A., Dahlberg, L.L. \& Zwi, A.B., 1996, 'World report on violence and health', The Lancet 360(9339), 1083-1088. http://dx.doi.org/10.1016/S01406736(02)11133-0

Lekwata, J., 2003, Integrated African liturgy, AMECEA, Kenya.

Lipsky, A.B., 2011, 'Evaluating the strength of faith: Potential comparative advantages of faith-based organisations providing health services in sub-Saharan Africa',
Public Administration and Development 31, 25-36. http://dx.doi.org/10.1002/ Public Admi
pad.586

Louw, D.J., 2008, Cura vitae: Illness and the healing of life, Lux Verbi, Wellington.

McClung, E, Grossoehme, D.H., \& Jacobson, A., 2006, 'Collaborating with chaplains to meet spiritual needs' Medsurg Nursing 15(3), 147-156.

Millennium Development Goals, n.d., viewed 26 May 2016, from http://www.who. int/mediacentre/factsheets

Miller-McLemore, B.J., 2012, Introduction: The contributions of practical, in B.J. Miller-McLemore (ed.), The Willey-Blackwell Companion to Practical Theology, pp. 1-20, Willey-Blackwell, Oxford.

Nagamia, H., 2003, 'Islamic medicine: History and current practice', Journal of ISHIM 2, 19-30, viewed 23 May 2013, from www.ishim.net/ishimj/14/o4.pdf

National Planning Commission of South Africa, 2011, National health development plan 2030, viewed 3 June 2014, from http://www.npconline.co.za/medialib/ download/home/NPC\%20National\%20Development $\% 20$ Plan $\% 20$ Vision $\% 20$ $30 \% 20$-lo-res.pdf

Neethling, I., 2003, 'The relevance of pastoral counselling in South Africa with reference to the South African Association for Pastoral Work', MTh dissertation, University of South Africa, Pretoria.

Olivier, J., 2015, 'Religion at the intersection of development and public health in development contexts: From advocacy about faith-based organisations to systems thinking', in E. Tomalin (ed.), The Routledge handbook of religion and global development, pp. 346-358, Routledge, New York.

Olivier, J. \& Wodon, Q., 2014, 'Playing broken telephone: Assessing faith-inspired health care provision in Africa', Development in Practice 22(5-6), 819-834.

Orton, M.J., 2008, 'Transforming chaplaincy: The emergence of a healthcare pastoral care for a post-modern world', Journal of Healthcare Chaplaincy 15(2), viewed 6 September 2011, from http://www.tandfonline.com.ez.sun.ac.za 
Osmer, R.R., 2008, Practical theology: An introduction, William B Eerdmans, Grand Rapids, MI.

Ott, M.R., 2007, 'Civil society and globalisation of its "State of Emergency": The longing for the totally other as a force of social change', in R Otto (ed.), The future of religion toward a reconciled society, pp. 273-306, Brill, Leiden.

Phiri, I., 2006, 'Dealing with trauma of sexual abuse: A gender-based analysis of the testimonies of female traditional healers, in Kwa-Zulu Natal', in I. Phiri \& S. Nada (eds.), African women, religion and health: Essays in honour of Mmercy Amber Ewudziwa Oduyoye, pp. 112-130, Cluster Publication, Pietermaritzburg.

Puchalski, C., Lunsford, B., Harris, M. \& Miller, T., 2006, 'Interdisciplinary spiritual care for seriously III and dying patients: A collaborative model', Cancer Journal 12 398-416, viewed 4 March 2014, from http://www.researchgate.net/---/6760009 intersisiplinary_spiritual_care

Rookes, P. \& Rookes, J., 2012, 'Have financial difficulties compounded Christian health services' commitment to the poor?', Development in Practice 22(5-6), 835-850. http://dx.doi.org/10.1080/09614524.2012.685869

Sachs, J., 2005, The end of poverty: How we can make it work, Penguin, London.

Sakurai, M., 2003, 'The challenge and heart of chaplaincy: Recent decades have brought a host of changes to health care chaplain's role', Health Progress 84(1):26-28, viewed 15 January 2013, from https://www.chausa.org

Schmid, B., Cochrane, J. \& Olivier, J., 2010, 'Understanding religious health assets: Health as a lens on religion and development', in I. Swart, H. Rocher, S. Green \& J. Erasmus (eds.), Religion and social development in post-apartheid South Africa: Perspectives for critical engagement, pp. 37-52, Sun Press, Stellenbosch.

Schmidt, K.W. \& Egler, G., 1998, 'A Christian for the Christians, a Muslim for the Muslims? Reflections on a protestant view of pastoral care for all religions', Christian Bioethics 4(3), 239-256. http://dx.doi.org/10.101697/chbi.4.3.239.68.96

Schneider-Harpprecht, C., 2003, 'Hospital chaplaincy across denominational, cultural and religious borders: Observations from the German context', Christian Bioethics $9(1), 91-107$, viewed 3 December 2012, from www.tandfonline.com/doiu/ abs/101076/chbi.9.17375
Smit, G., 2015, 'Pastoral Ministry in a missional age: Towards a practical theological understanding of missional pastoral care', Verbum et Ecclesia 36(1), 1-8. http:// dx.doi.org/10.4102/ve.v36i1.1382

Ter Haar, G. \& Ellis, S., 2006, 'The role of religion in development: Towards a new relationship between the European Union and Africa', European Journal of Development Research 18(3), 351-367. http://dx.doi.org/10.1080/095788106 0089340.3

Tovino, S., 2005, 'Hospital chaplaincy under the HIPAA privacy rule: Health care or "Just Visiting the Sick"?', Indiana Health Law Review 2(49), 51-93, viewed 1 September 2011, from http://www.heinonline.org

Unuhu, F.T., Ebiti, N.W., Oju, G.O. \& Aremu, S.B., 2009, 'Anorexia nervosa in a Nigerian patient - A case report', Nigerian Medical Journal 50(1), 23-24.

VandeCreek, L.D., 2010, 'Defining and advocating for spiritual care in the hospital', Journal of Pastoral Care and Counselling 64(2), 1-10. http://dx.doi.org/10.1177/ 154230501006400205

Wepener, C., Swart, I., Ter Haar, G. \& Barnard, M., 2010, 'The role of religious ritual in social capital formation for poverty alleviation and social development Theoretical and methodological points of departure of a South African exploration', Religion and Theology 17, 61-82. http://dx.doi.org/10.1163/157430 $110 \times 517924$

World Health Organization (WHO), 2000, World health report: How well do health systems perform?, viewed 23 May 2014, from http://www.who.int/whr/2000/en/ whr00_ch2_en.pdf

World Health Organization (WHO), 2010, Key components of a well-functioning health system, viewed 16 August 2012, from http://who.int/healthsystem/EN_ HSSkeycomponents. pdf

World Health Organization (WHO), 2014, World health statistics, viewed 4 June 2014 from http://appa.who.int/iris/bitstream/10665/112738/1/9789240692671_eng. pdf

World Health Statistics Part III, 2014, Global health indicators, viewed 4 June 2014 from http://www.who.int/gho/publications 